\title{
Chemical composition and bioactive properties of the wild edible plant Raphanus raphanistrum $\mathrm{L}$
}

\author{
Júlia Harumi Iyda ${ }^{\mathrm{a}, \mathrm{b}}$, Ângela Fernandes ${ }^{\mathrm{a}}$, Flávio Dias Ferreira ${ }^{\mathrm{b}}$, Maria José Alves ${ }^{\mathrm{a}}$, \\ Tânia C.S.P. Pires ${ }^{\mathrm{a}}$, Lillian Barros ${ }^{\mathrm{a}}$, Joana S. Amaral ${ }^{\mathrm{a}, \mathrm{c}, *}$, Isabel C.F.R. Ferreira ${ }^{\mathrm{a}, *}$ \\ ${ }^{a}$ Centro de Investigação de Montanha (CIMO), Instituto Politécnico de Bragança, Campus de Santa Apolónia, 5300-253 Bragança, Portugal \\ ${ }^{\mathrm{b}}$ Departamento Acadêmico de Alimentos (DAALM), Universidade Tecnológica Federal do Paraná, Campus Medianeira, 85884-000 Paraná, Brazil \\ ${ }^{\mathrm{c}}$ REQUIMTE/LAQV, FFUP, 4050-313 Porto, Portugal
}

\section{A R T I C L E I N F O}

\section{Keywords:}

Raphanus raphanistrum

Wild radish

Nutritional value

Chemical characterization

Bioactive properties

\begin{abstract}
A B S T R A C T
Recently, there has been an interest regarding the consumption of wild edible plants in modern diets. However, there is still scarce information about several wild vegetables traditionally consumed. Therefore, this work aims on documenting the nutritional and chemical composition of wild radish (Raphanus raphanistrum L.), as well as its bioactive potential. Results showed that wild radish is a potential source of beneficial compounds, including vitamin E, polyunsaturated fatty acid (particularly $\alpha$-linolenic acid) and different phenolic compounds, in which fourteen phenolics were identified, with kaempferol-3,7-O-di-rhamnoside being the most abundant. The bioactive potential was exploited using hydroethanolic and decoction extracts. Both proved to inhibit several Gram-positive and Gram-negative bacteria and revealed antioxidant activity, while cytotoxicity against nontumor cell was not observed. In general, results evidence the interest in recovering the use of this wild vegetable as part of a varied diet, which can bring several health benefits.
\end{abstract}

\section{Introduction}

Since ancient times, wild edible plants are collected by humans to be used as a food source. Additionally, due to the presence of biologically active compounds, many of these plants, or their parts, are also used in traditional medicine (Ferreira, Morales, \& Barros, 2016). Along the history, wild edible plants have played an important role, in particular during times of famine and scarcity. Nowadays, they are still being exploited on a daily basis in several developing countries to provide an adequate level of nutrition. In contrast, they are underutilized in modern societies, mainly due to life-style changes caused by industrialization and urbanization. Notwithstanding, because they are part of the cultural heritage of several regions in the world, they continue to be traditionally consumed by different communities, mainly in rural regions (Pinela, Carvalho, \& Ferreira, 2017). In addition, more recently, there is a growing interest of consumers regarding several wild plants since their consumption is being promoted by some culinary chefs, more information about composition and associated health benefits is being disseminated and there is a rising concern about the quality of mass-produced crops. Also, the importance of these natural resources in food security has been increasingly emphasized worldwide (Łuczaj et al., 2012).
The wild edible plant Raphanus raphanistrum L., commonly designated as wild radish (or as "labrestos" or "saramagos" in Portuguese) (Bicho, 2015), belongs to the Brassicaceae family, being characterized as an erect herb, with trichomes distributed along the plant, pubescent and alternated leaves and actinomorphic flowers, clearly veined, with coloration ranging from white to violet (Scalon \& Souza, 2002). This specie is native from Europe, being mostly found in the southern Europe and all over the Mediterranean region. Because it is distributed in temperate and subtropical climate regions, its habitat is extremely vast, being also frequently found in the southeast of United States of America and southern Australia (Scalon \& Souza, 2002). Among the different parts of the plant that may have edible use (leaves, young stems, flowers, roots and seeds), the leaves are the most frequently consumed. These have a slightly spicy taste and can be eaten either raw in salads or cooked in soups and as boiled vegetables (Maldini et al., 2017).

So far, there is a lack of information about this wild vegetable, with the existing data referring only to its composition in glucosinolates (Maldini et al., 2017). Therefore, in this study, the leaves of wild radish were thoroughly characterized in terms of its nutritional and chemical composition, giving special attention to the bioactive properties of hydroalcoholic and decoctions extracts, aiming to valorize $R$. raphanistrum as a traditionally used wild vegetable that can be included in

\footnotetext{
* Corresponding authors.

E-mail addresses: jamaral@ipb.pt (J.S. Amaral), iferreira@ipb.pt (I.C.F.R. Ferreira).
} 
modern diets.

\section{Materials and methods}

\subsection{Samples}

Leaves in a mature stage of Raphanus raphanistrum L. were collected during October 2017 from plants growing wild in Vila Real, Portugal ( $41^{\circ} 17^{\prime} 34^{\prime \prime} \mathrm{N}, 7^{\circ} 47^{\prime} 16^{\prime \prime} \mathrm{W}, 614 \mathrm{~m}$ a.s.l.). Three lots of freshly harvested leaves ( $\sim 100 \mathrm{~g}$ each one) were collected and lyophilized (FreeZone 4.5, Labconco, MO, USA). A specimen voucher was deposited in the herbarium of the School of Agriculture, Polytechnic Institute of Bragança (Portugal). The dry leaves were crushed to a fine powder (20 mesh) and stored in the best condition (protected from light and humidity) until analysis was performed.

\subsection{Hydroalcoholic and decoction extracts}

Hydroalcoholic extractions were performed by stirring the plant material $(2.5 \mathrm{~g})$ with $30 \mathrm{~mL}$ of ethanol/water $(80: 20, v / v)$ at $25^{\circ} \mathrm{C}$, under magnetic stirring for $1 \mathrm{~h}$ and filtered through Whatman No. 4 paper. The residue was then re-extracted with additional $30 \mathrm{~mL}$ of the hydroalcoholic mixture. The combined extracts were evaporated at $40^{\circ} \mathrm{C}$ under reduced pressure (rotary evaporator Büchi R-210, Flawil, Switzerland) and further lyophilized (FreeZone 4.5, Labconco, Kansas City, MO, USA).

Decoctions were performed by adding $200 \mathrm{~mL}$ of distilled water to the sample $(1 \mathrm{~g})$, and boiled for $5 \mathrm{~min}$ (heating plate, VELP scientific). Subsequently, the mixtures were left to stand for $5 \mathrm{~min}$ and then filtered through Whatman No. 4 paper. The obtained decoctions were frozen and lyophilized.

\subsection{Chemical parameters}

\subsubsection{Nutritional compounds and energetic value}

Sample were analysed in terms of nutritional compounds (moisture, fat, ash, proteins and carbohydrates) according to the AOAC methods (AOAC, 2016). Briefly, moisture was determined by drying fresh leaves at $105 \pm 5^{\circ} \mathrm{C}$ until constant weight. Crude protein was evaluated by macro-Kjeldahl method $(N \times 6.25)$ using an automatic distillation and titration unit (model Pro-Nitro-A, JP Selecta, Barcelona) (AOAC 978.04), ash content was determined by incineration at $600 \pm 15^{\circ} \mathrm{C}$ (AOAC 923.03), and the crude fat was determined by extraction with petroleum ether using a Soxhlet apparatus (AOAC 920.85). Total carbohydrates were determined by difference according to the equation:

Total carbohydrates $(\mathrm{g} / 100 \quad \mathrm{~g} \quad \mathrm{fw})=100-\left(\mathrm{g}_{\text {moisture }}+\mathrm{g}_{\text {fat }}\right.$ $\left.+\mathrm{g}_{\text {ash }}+\mathrm{g}_{\text {proteins }}\right)$.

Energy was determined according to the Atwater system following the equation:

$(\mathrm{kcal} / 100 \mathrm{~g} \mathrm{fw})=4 \times\left(\mathrm{g}_{\text {proteins }}+\mathrm{g}_{\text {carbohydrates }}\right)+9 \times\left(\mathrm{g}_{\mathrm{fat}}\right)$.

\subsubsection{Free sugars}

Free sugars were determined in the lyophilized sample and in both extracts (hydroalcoholic and decoction), using melezitose (Matreya, PA, USA) as internal standard (IS). The lyophilized sample was extracted using a methodology previously described (Barros et al., 2013), while the hydroalcoholic and decoction extracts $(30 \mathrm{mg}$ ) were re-dissolved in $2 \mathrm{~mL}$ of distilled water and filtered through a $0.22 \mu \mathrm{m}$ disposable LC filter disk. The compounds separation was performed using a high performance liquid chromatography system coupled with a refraction index detector (HPLC-RI, Knauer, Smartline system 1000, Berlin, Germany), using a Eurospher 100-5 NH2 column $(4.6 \times 250 \mathrm{~mm}, 5 \mathrm{~mm}$, Knauer), operating at $35^{\circ} \mathrm{C}$ (7971 R Grace oven) for chromatographic separation as previously described by Barros et al. (2013). Compounds were identified by comparison with standards $(\mathrm{D}(-)$-fructose:, $\mathrm{D}$ $(+)$-sucrose, $\mathrm{D}(+)$-glucose, $\mathrm{D}(+)$-trehalose and $\mathrm{D}(+)$-raffinose pentahydrate, Sigma-Aldrich (St. Louis, MO, USA), and quantification (calibration curves $24-0.625 \mathrm{mg} / \mathrm{mL}$ ) was performed by the IS method. Results were processed using the Clarity 2.4 software (DataApex, Prague, Czech Republic) and expressed in $\mathrm{g}$ per $100 \mathrm{~g}$ of fresh weight (fw) or in mg per g extract, for plant or the extracts, respectively.

\subsubsection{Organic acids}

Organic acids were determined in the lyophilized sample and in both extracts (hydroalcoholic and decoction). The lyophilized sample was extracted using a methodology previously described and optimized (Barros et al., 2013) while the extracts $(10 \mathrm{mg}$ ), were re-dissolved in $1 \mathrm{~mL}$ of metaphosphoric acid (4.5\%) and filtered through a $0.22 \mu \mathrm{m}$ disposable LC filter disk. The analysis was performed by ultra-fast liquid chromatography coupled with a diode-array detector (UFLC-PDA, Shimadzu Corporation, Japan) as previously described (Barros et al., 2013). Compounds were identified and quantified (calibration curves ranging from 10 to $0.008 \mathrm{mg} / \mathrm{mL}$ for oxalic, quinic, malic, ascorbic, citric, while fumaric acid $400-3125 \mu \mathrm{g} / \mathrm{mL}$ ) by comparison of the retention time, spectra and peak area recorded at $245 \mathrm{~nm}$ and $215 \mathrm{~nm}$ (for ascorbic acid and remaining acids, respectively), with those obtained from commercial standards (oxalic, quinic, malic, ascorbic, citric and fumaric acids, Sigma-Aldrich, St. Louis, MO, USA). The results were recorded and processed using LabSolutions Multi LC-PDA software (Shimadzu Corporation, Kyoto, Japan), and were expressed in $\mathrm{g} / 100 \mathrm{~g}$ fw or in mg per $g$ extract, for plant or the extracts, respectively.

\subsubsection{Fatty acids}

Fatty acids were determined by gas-liquid chromatography with flame ionization detection (GC-FID), after the extraction and derivatization procedures previously described by Obodai et al. (2017). The analysis was carried out with a DANI model GC 1000 instrument equipped with a split/splitless injector, a flame ionization detector (FID) set at $260{ }^{\circ} \mathrm{C}$ and a Zebron-Kame column $(30 \mathrm{~m} \times 0.25 \mathrm{~mm}$ ID $\times 0.20 \mu \mathrm{m} d f$, Phenomenex, Lisbon, Portugal). The oven temperature program was as follows: the initial temperature of the column was $100^{\circ} \mathrm{C}$, held for $2 \mathrm{~min}$, then a $10^{\circ} \mathrm{C} / \mathrm{min}$ ramp to $140^{\circ} \mathrm{C}, 3^{\circ} \mathrm{C} / \mathrm{min}$ ramp to $190^{\circ} \mathrm{C}, 30^{\circ} \mathrm{C} / \mathrm{min}$ ramp to $260^{\circ} \mathrm{C}$ and held for $2 \mathrm{~min}$. The carrier gas (hydrogen) operated at a constant flow-rate of $1.1 \mathrm{~mL} / \mathrm{min}$, measured at $100{ }^{\circ} \mathrm{C}$. Split injection $(1: 50)$ was carried out at $250^{\circ} \mathrm{C}$. Fatty acids identification and quantification (Clarity DataApex 4.0 Software, Prague, Czech Republic) were performed by comparing the relative retention times of fatty acid methyl ester (FAME) peaks from samples with standards (reference standard mixture 47,885-U, Sigma, St. Louis, MO, USA). Results were expressed in $\mathrm{mg}$ per $100 \mathrm{~g}$ fw of each detected fatty acid.

\subsubsection{Tocopherols}

Tocopherols were determined in the lyophilized sample and in both extracts (hydroalcoholic and decoction). The lyophilized sample was extracted as previously described (Barros, Carvalho, Morais, \& Ferreira, 2010) while the extracts ( $40 \mathrm{mg}$ ), were re-dissolved in $2 \mathrm{~mL}$ of hexane and filtered through a $0.22 \mu \mathrm{m}$ disposable LC filter disk. Separation, identification and quantification of the compounds were performed using a HPLC system coupled to a fluorescence detector (FP-2020; Jasco, Easton, USA) programmed for excitation at $290 \mathrm{~nm}$ and emission at $330 \mathrm{~nm}$ (Barros et al., 2013) using tocol (Matreya, Pleasant Gap, PA, USA) as internal standard. Tocopherols standards $(\alpha-, \beta-, \gamma-$, and $\delta$ isoforms, Sigma-Aldrch, St. Louis, MO, USA) were used for compounds identification and quantification $(0.075$ to $8 \mu \mathrm{g} / \mathrm{mL})$ by the internal standard method. The results were processed using the Clarity 2.4 software (DataApex, Prague) and expressed in $\mathrm{mg} / 100 \mathrm{~g}$ fw or $\mathrm{mg}$ per $\mathrm{g}$ extract, for sample and extracts, respectively.

\subsubsection{Phenolic compounds}

The extracts were re-dissolved in methanol/water $(80: 20, v / v$, $5 \mathrm{mg} / \mathrm{mL}$ ) and filtered through a $0.22 \mu \mathrm{m}$ disposable LC filter disk. 
Phenolic compounds were evaluated using a Dionex Ultimate 3000 UPLC (Thermo Scientific, San Jose, CA, USA) system equipped with a diode array detector $(280,330$ and $370 \mathrm{~nm}$ as preferred wavelengths) coupled to an electrospray ionization mass spectrometry detector (MS), operating under the conditions described by Bessada, Barreira, Barros, Ferreira, and Oliveira (2016). Chromatographic separation was achieved with a Waters Spherisorb S3 ODS-2 C18 $(3 \mu \mathrm{m}$, $4.6 \mathrm{~mm} \times 150 \mathrm{~mm}$, Waters, Milford, MA, USA) column thermostatted at $35{ }^{\circ} \mathrm{C}$. The solvents used were: (A) $0.1 \%$ formic acid in water, (B) acetonitrile. MS detection was performed in negative mode, using a Linear Ion Trap LTQ XL mass spectrometer (Thermo Finnigan, San Jose, CA, USA) equipped with an ESI source. Nitrogen served as the sheath gas (50 psi); the system was operated with a spray voltage of $5 \mathrm{kV}$, a source temperature of $325^{\circ} \mathrm{C}$, a capillary voltage of $-20 \mathrm{~V}$. The tube lens offset was kept at a voltage of $-66 \mathrm{~V}$. The full scan covered the mass range from $m / z 100$ to 1500 . The collision energy used was 35 (arbitrary units). Data acquisition was carried out with Xcalibur ${ }^{\circledR}$ data system (ThermoFinnigan, San Jose, CA, USA).

The identification was made by comparison of retention times, UVVIS and mass spectra of the sample compounds with those obtained from the available standards, as also with reported data from literature, and tentatively identified by using the fragmentation pattern. The phenolic compound estimation was made using the calibration curves obtained from standards $(200-5 \mu \mathrm{g} / \mathrm{mL} ; p$-coumaric acid, ferulic acid and quercetin-3-O-glucoside, Extrasynthese, Genay, France), which were constructed based on the UV-Vis signal (280, 330, and $370 \mathrm{~nm})$. A manual integration using baseline to valley integration mode with baseline projection was performed to obtained the area of the peaks. The results were expressed in $\mathrm{mg} / \mathrm{g}$ extract.

\subsection{Bioactive properties}

\subsubsection{Evaluation of in vitro antioxidant properties}

The extracts were re-dissolved in ethanol:water (80:20, $v / v)$ and water for hydroalcoholic and decoctions extracts, respectively, at a final concentration of $5 \mathrm{mg} / \mathrm{mL}$ and further diluted at different concentrations (in the range of $5-0.0391 \mathrm{mg} / \mathrm{mL}$ ) to perform the distinct in vitro assays. The antioxidant potential was evaluated by the DPPH radicalscavenging activity, reducing power, $\beta$-carotene bleaching inhibition and lipid peroxidation inhibition (LPI) assays, as previously described (Sarmento, Barros, Fernandes, Carvalho, \& Ferreira, 2015).

2.4.1.1. DPPH radical scavenging activity. This methodology was performed using an ELX800 microplate reader (Bio-Tek Instruments, Inc.). Different concentrations of the extracts $(30 \mu \mathrm{L})$ and methanolic solution $(270 \mu \mathrm{L})$ containing 2,2-diphenyl-1-picrylhydrazyl radicals (DPPH, $6 \times 10^{-5} \mathrm{~mol} / \mathrm{L}$, Alfa Aesar, Ward Hill, MA, USA) were mixed and left to stand in the dark for $30 \mathrm{~min}$. The reduction of the DPPH radical was determined by measuring the absorption at $515 \mathrm{~nm}$.

2.4.1.2. Reducing power. Was performed using the Microplate Reader described above. The different concentrations of the extracts $(0.5 \mathrm{~mL})$ were mixed with sodium phosphate buffer $(200 \mathrm{mmol} / \mathrm{L}, \mathrm{pH} 6.6$, $0.5 \mathrm{~mL}$ ) and potassium ferricyanide $(1 \mathrm{~g} / 100 \mathrm{~mL}, 0.5 \mathrm{~mL})$. For each concentration, the mixture was incubated at $50{ }^{\circ} \mathrm{C}$ for $20 \mathrm{~min}$, and trichloroacetic acid $(10 \mathrm{~g} / 100 \mathrm{~mL}, 0.5 \mathrm{~mL})$ was added. The mixture $(0.8 \mathrm{~mL})$ was poured in the 48 -wells, as also deionised water $(0.8 \mathrm{~mL})$ and ferric chloride $(0.1 \mathrm{~g} / 100 \mathrm{~mL}, 0.16 \mathrm{~mL})$, and the absorbance was measured at $690 \mathrm{~nm}$.

2.4.1.3. Inhibition of $\beta$-carotene bleaching. Was assessed through the $\beta$ carotene/linoleate assay, measured at $470 \mathrm{~nm}$, and determined using the following equation:

( $\beta$ - carotene absorbance after2 hof assay/initial absorbance) $\times 100$.
2.4.1.4. TBARS (thiobarbituric acid reactive substances) assay. Was assessed in porcine brain homogenates by measuring the decreasing of thiobarbituric acid reactive substances (TBARS) at the absorbance of $532 \mathrm{~nm}$. Lipid peroxidation inhibition (\%) was calculated using the following equation:

$[(\mathrm{A} \times \mathrm{B}) / \mathrm{A}] \times 100 \%$.where $\mathrm{A}$ and $\mathrm{B}$ were the absorbance of the control and the sample solution, respectively.

The results of the assays were expressed as $\mathrm{EC}_{50}$, corresponding to the extract concentrations providing $50 \%$ of antioxidant activity, calculated from the graphs of antioxidant activity percentages (DPPH assay, $\beta$-Carotene bleaching inhibition and lipid peroxidation inhibition) against extract concentrations or 0.5 of absorbance at $690 \mathrm{~nm}$ in the case of the reducing power assay. Trolox (Sigma-Aldrich, St. Louis, MO, USA) was used as a standard.

\subsubsection{Antimicrobial activity}

Antimicrobial activity was evaluated using the broth microdilution method according to Pires et al. (2018). The microorganisms used were clinical isolates and included three Gram-positive bacteria (Enterococcus faecalis, Listeria monocytogenes and methicillin-resistant Staphylococcus aureus) and five Gram-negative bacteria (Escherichia coli, Klebisiella pneumoniae, Morganela morganii, Proteus mirabilis and Pseudomonas aeruginosa). The minimum inhibitory concentration (MIC) was determined for the hydroalcoholic and decoction extracts and evaluated through the colorimetric microbial viability based on the reduction of iodonitrotetrazolium chloride $(0.2 \mathrm{mg} / \mathrm{mL})$. The minimum bactericidal concentration (MBC) was evaluated by plating the content of the microwells that did not present coloration in the MIC assay. Different antibiotics were used as negative control, namely ampicillin and imipenem for Gram-negative bacteria, and vancomycin and ampicillin for Gram-positive bacteria. A positive control was prepared using culture broth Muller Hinton Broth (MHB) or Tryptic Soy Broth (THB) plus 5\% of dimethyl sulfoxide (DMSO) inoculated with each tested bacteria.

\subsubsection{Hepatotoxic activity}

Was evaluated following the method described by Abreu et al. (2011), using a primary cell culture (PLP2) prepared from a porcine liver and different concentrations of the hydroalcoholic or decoction extracts, ranging from $400 \mu \mathrm{g} / \mathrm{mL}$ to $6.5 \mu \mathrm{g} / \mathrm{mL}$. The results were measured through the Sulforhodamine B method and results were expressed as $\mathrm{GI}_{50}$ values (concentration that inhibits $50 \%$ of cell growth). Ellipticine was used as positive control.

\subsection{Statistical analysis}

For each analysis three samples were used and all assays were performed in triplicate. The results were expressed as mean \pm standard deviation (DP). The results were analysed by a 1 -variance analysis (ANOVA) followed by Tukey's HSD test with $\alpha=0.05$. In case there were less than three sample groups, the results were analysed using a Student's $t$-test. The statistical treatment was performed by the SPSS v. 23.0.

\section{Results and discussion}

\subsection{Chemical characterization of $R$. raphanistrum}

The results of the nutritional value, free sugars and organic acids composition are shown in Table 1. Carbohydrates were the most abundant nutritional compound, followed by proteins, ash and lipids. This is in agreement with the nutritional compounds content reported by Kala and Prakash (2006) for a $R$. raphanistrum sample from India. However, a higher amount of moisture $(94.60 \mathrm{~g} / 100 \mathrm{~g} \mathrm{fw})$, and lower content of protein, ash and lipids $(0.55,0.55$ and $0.06 \mathrm{~g} / 100 \mathrm{~g} \mathrm{fw}$, respectively) were reported in comparison with the plant studied in this work. This may occur due to the different climatic and soil conditions 
Table 1

Nutritional value, energetic value, free sugars and organic acids of the studied plant $R$. raphanistrum (mean $\pm \mathrm{SD}$ ).

\begin{tabular}{|c|c|}
\hline \multicolumn{2}{|l|}{ Nutritional value } \\
\hline Moisture & $89.9 \pm 0.6$ \\
\hline Ash $(g / 100 g$ fw $)$ & $1.58 \pm 0.08$ \\
\hline Proteins $(\mathrm{g} / 100 \mathrm{~g} \mathrm{fw})$ & $4.04 \pm 0.01$ \\
\hline Lipids $(\mathrm{g} / 100 \mathrm{~g} \mathrm{fw})$ & $0.23 \pm 0.03$ \\
\hline Carbohydrates $(\mathrm{g} / 100 \mathrm{~g}$ fw) & $4.22 \pm 0.08$ \\
\hline Energy (kcal/100 g fw) & $35.1 \pm 0.1$ \\
\hline \multicolumn{2}{|l|}{ Free sugars $(\mathrm{g} / 100 \mathrm{~g} \mathrm{fw})$} \\
\hline Fructose & $0.153 \pm 0.004$ \\
\hline Glucose & $0.348 \pm 0.003$ \\
\hline Trehalose & $0.034 \pm 0.001$ \\
\hline Total free sugars & $0.53 \pm 0.01$ \\
\hline \multicolumn{2}{|l|}{ Organic acids $(\mathrm{g} / 100 \mathrm{~g} \mathrm{fw})$} \\
\hline Oxalic acid & $0.706 \pm 0.001$ \\
\hline Quinic acid & $0.62 \pm 0.01$ \\
\hline Malic acid & $0.58 \pm 0.01$ \\
\hline Ascorbic acid & $0.008 \pm 0.001$ \\
\hline Citric acid & $0.613 \pm 0.005$ \\
\hline Fumaric acid & $0.005 \pm 0.001$ \\
\hline Total organic acids & $2.54 \pm 0.01$ \\
\hline \multicolumn{2}{|c|}{$\begin{array}{l}\text { Free sugars calibration curves: fructose }\left(\mathrm{y}=1.04 \times, R^{2}=0.999 ;\right. \\
\mathrm{LOD}=0.05 \mathrm{mg} / \mathrm{mL} ; \mathrm{LOQ}=0.18 \mathrm{mg} / \mathrm{mL}), \text { glucose }(\mathrm{y}=0.935 \times \text {, } \\
\left.R^{2}=0.999 ; \mathrm{LOD}=0.08 \mathrm{mg} / \mathrm{mL} ; \mathrm{LOQ}=0.25 \mathrm{mg} / \mathrm{mL}\right) \text { and trehalose } \\
\left(y=0.991 \times, R^{2}=0.999 ; \mathrm{LOD}=0.07 \mathrm{mg} / \mathrm{mL}, \mathrm{LOQ}=0.24 \mathrm{mg} /\right. \\
\mathrm{mL}) .\end{array}$} \\
\hline \multicolumn{2}{|c|}{$\begin{array}{l}\text { Organic acids calibration curves: oxalic acid }\left(\mathrm{y}=9 \times 10^{6}\right. \\
\left.\mathrm{x}+377,946 ; R^{2}=0.994 ; \mathrm{LOD}=12.55 \mu \mathrm{g} / \mathrm{mL} ; \mathrm{LOQ}=41.82 \mu \mathrm{g} / \mathrm{mL}\right) \\
\text { quinic acid }\left(\mathrm{y}=612,327 \times+16,563 ; R^{2}=1 ; \mathrm{LOD}=24.18 \mu \mathrm{g} / \mathrm{mL} ;\right. \\
\mathrm{LOQ}=80.61 \mu \mathrm{g} / \mathrm{mL}) ; \quad \text { malic acid }(\mathrm{y}=863,548 \times+55,591 ; \\
\left.R^{2}=0.999 ; \mathrm{LOD}=35.76 \mu \mathrm{g} / \mathrm{mL} ; \mathrm{LOQ}=119.18 \mu \mathrm{g} / \mathrm{mL}\right) ; \text { ascorbic } \\
\text { acid }\left(\mathrm{y}=7 \mathrm{E}+07 \times+60,489 ; R^{2}=0,999 ; \mathrm{LOD}=367 \mu \mathrm{g} / \mathrm{mL} ; \mathrm{LOQ}\right. \\
=1222 \mu \mathrm{g} / \mathrm{mL}) ; \mathrm{citric} \text { acid }\left(\mathrm{y}=1 \times 10^{6} \mathrm{x}+16,276 ; R^{2}=1 ; \mathrm{LOD}=\right. \\
10.47 \mu \mathrm{g} / \mathrm{mL} ; \mathrm{LOQ}=34.91 \mu \mathrm{g} / \mathrm{mL}) \text { and fumaric acid }(\mathrm{y}=148,083 \times \\
\left.+96,092 ; R^{2}=1 ; \mathrm{LOD}=0.08 \mu \mathrm{g} / \mathrm{mL} ; \mathrm{LOQ}=0.26 \mu \mathrm{g} / \mathrm{mL}\right) .\end{array}$} \\
\hline
\end{tabular}

(de Oliveira et al., 2016). Although, a comparable content of total carbohydrates was found for both Indian and Portuguese samples (4.22 vs $4.23 \mathrm{~g} / 100 \mathrm{~g} \mathrm{fw}$ ) (Kala \& Prakash, 2006).

Comparing the obtained results with those reported for commonly consumed species belonging to the Brassicaceae family (Brassica oleracea var. acephala (cabbage), Brassica juncea (mustard greens), Raphanus sativus (red radish)), one can observe that all presented a very high content of moisture, with $R$. raphanistrum presenting the most abundant content in protein and lowest lipid contents (Goyeneche et al., 2015; NEPA, 2011; USDA, 2016). Compared to $R$. raphanistrum leaves, $R$. sativus was the one presenting the most identical nutritional profile (crude protein $3.81 \mathrm{~g} / 100 \mathrm{~g} \mathrm{fw}$, ash $1.70 \mathrm{~g} / 100 \mathrm{~g}$ fw, total carbohydrates $4.04 \mathrm{~g} / 100 \mathrm{~g}$ fw and lipids $0.37 \mathrm{~g} / 100 \mathrm{~g} \mathrm{fw}$ ) (Goyeneche et al., 2015). This is most probably related to the fact that both these species belong to the same genus.

The energetic value calculated for the leaves of $R$. raphanistrum was considerably low, which makes this plant suitable for low carb diets, simultaneous allowing a higher diversification of the consumed food (Morales et al., 2012).

$R$. raphanistrum presented simultaneously three free sugars, namely the disaccharide trehalose and two monosaccharides, glucose and fructose. The predominant compound was glucose, the most prevalent sugar in nature, followed by fructose and smaller amounts of trehalose (Table 1). Organic acids are known to affect some characteristics of vegetables, such as flavour, aroma and appearance. It has been reported that malic acid has a strong permanent taste, which is not immediately perceived, while citric acid has pronounced and momentary flavour, which resembles lemon (Food Ingredients Brasil, 2015). Besides affecting the organoleptic characteristics of foods, organic acids can also
Table 2

Composition of fatty acids and tocopherols (mg/100 g fw) of $R$. raphanistrum leaves (mean $\pm \mathrm{SD}$ ).

\begin{tabular}{ll}
\hline Fatty acids & \\
\hline C6:0 & $0.14 \pm 0.02$ \\
C8:0 & $0.13 \pm 0.02$ \\
C10:0 & $0.068 \pm 0.006$ \\
C12:0 $14: 0$ & $0.27 \pm 0.02$ \\
C15:0 & $0.44 \pm 0.05$ \\
C16:0 & $0.44 \pm 0.04$ \\
C16:1 & $25.2 \pm 2.3$ \\
C17:0 $18: 0$ & $0.31 \pm 0.03$ \\
C18:1n9 & $0.40 \pm 0.03$ \\
C18:2n6 & $3.6 \pm 0.3$ \\
C18:3n3 & $2.4 \pm 0.3$ \\
C20:0 & $24 \pm 2$ \\
C20:2 & $171 \pm 16$ \\
C20:3n3 + C21:0 & $0.52 \pm 0.04$ \\
C20:5n3 & $0.32 \pm 0.03$ \\
C22:0 & $0.71 \pm 0.07$ \\
C22:1n9 & $0.14 \pm 0.01$ \\
C24:0 & $1.07 \pm 0.08$ \\
C24:1 & $0.87 \pm 0.09$ \\
SFA & $0.51 \pm 0.06$ \\
MUFA & $0.79 \pm 0.09$ \\
PUFA & $33 \pm 3$ \\
Tocopherols & $4.4 \pm 0.5$ \\
$\alpha$-Tocopherol & $196 \pm 18$ \\
$\gamma$-Tocopherol & \\
$\delta$-Tocopheopherol & \\
Total tocopherols & $0.89 \pm 0.01$ \\
\hline C6: - Can & $0.041 \pm 0.002$ \\
& $0.084 \pm 0.003$ \\
& $0.052 \pm 0.001$ \\
& $1.07 \pm 0.01$ \\
\hline
\end{tabular}

C6:0 - Caproic acid; C8:0 - Caprylic acid; C10:0 - Capric acid; C12:0 - Lauric acid; C14:0 - Myristic acid; C15:0 Pentadecanoic acid; C16:0 - Palmitic acid; C16:1 Palmitoleic acid; C17:0 - Heptadecanoic acid; C18:0 Stearic acid; C18:1n9 - Oleic acid; C18:2n6 - Linoleic acid; C18:3n3 - Linolenic acid; C20:0 - Arachidic acid; C20:2 cis-11,14 - Eicosadienoic acid; C20:3n3 + C21:0 Eicosatrienoic acid and Heneicosanoic acid; C20:5n3 Eicosapentaenoic acid; C22:0 - Behenic acid; C22:1n9 Erucic acid; C24:0 - Lignoceric acid; C24:1 - Nervonic acid. SFA: Saturated Fatty Acids; MUFA: Monounsaturated Fatty Acids; PUFA: Polyunsaturated Fatty Acids.

Tocopherols calibration curves: $\alpha$-tocopherol ( $\mathrm{y}=1.295 \times$; $R^{2}=0.991$; LOD: $18.06 \mathrm{ng} / \mathrm{mL}$, LOQ: $\left.60.20 \mathrm{ng} / \mathrm{mL}\right) ; \beta$-tocopherol $\left(\mathrm{y}=0.396 \times ; R^{2}=0.992\right.$; LOD: $25.82 \mathrm{ng} / \mathrm{mL}$, LOQ: $\quad 86.07 \mathrm{ng} / \mathrm{mL}) ; \quad \gamma$-tocopherol $\quad(\mathrm{y}=0.567 \times$; $R^{2}=0.991$; LOD: $14.79 \mathrm{ng} / \mathrm{mL}$, LOQ: $\left.49.32 \mathrm{ng} / \mathrm{mL}\right) ; \delta$-tocopherol $\left(\mathrm{y}=0.678 \times ; R^{2}=0.992 ;\right.$ LOD: $20.09 \mathrm{ng} / \mathrm{mL}$, LOQ: $66.95 \mathrm{ng} / \mathrm{mL})$.

interfere in the microbial stability, nutritional value and consumers acceptability, being frequently used in the food industry as acidifying compounds (Santos, 2013). In this work, six organic acids were identified in $R$. raphanistrum leaves (Table 1), with oxalic acid being the predominant compound, followed by quinic, citric and malic acids. It is known that vegetables with high concentration of oxalic acid, such as $S$. oleracea $(0.97 \mathrm{~g} / 100 \mathrm{~g})$, Beta vulgaris L. (beet leaves, $0.61 \mathrm{~g} / 100 \mathrm{~g}$ ) or Petroselinum crispum (Mill.) Nym. (parsley, $1.7 \mathrm{~g} / 100 \mathrm{~g}$ ) leaves (USDA, 2016) should be consumed moderately, because the high intake of oxalates may promote kidney stones, intestinal mucosa irritation and also interferes in calcium absorption (Benevides, de, Souza, Souza, \& Lopes, 2011; Vega \& Florentino, 2000). Although the content of oxalic acid present in $R$. raphanistrum $(0.706 \mathrm{~g} / 100 \mathrm{~g} \mathrm{fw})$ was lower than that of spinach and parsley, it is reasonably high, being greater than that found in several vegetables, including red radish leaves $(0.48 \mathrm{~g} / 100 \mathrm{~g})$. Therefore, its consumption should be avoided by individuals prone to 
develop diseases such as kidney stones, arthritis, gout and rheumatism (Benevides et al., 2011).

Table 2 presents the fatty acid profile of $R$. raphanistrum leaves, showing that polyunsaturated fatty acids (PUFA) was the major group, followed by saturated fatty acids (SFA) and monounsaturated fatty acids (MUFA). A total of 22 fatty acids were identified in the wild radish leaves, representing, to the best of our knowledge, the first report on the fatty acid composition of this species Wild radish leaves presented a predominant composition of unsaturated fatty acids, particularly omega-3 $(\omega-3)$ PUFA, due to the high content of $\alpha$-linolenic acid (C18:3n3; $171 \mathrm{mg} / 100 \mathrm{~g} \mathrm{fw}$ ). Similar results were also observed in several other wild edible green vegetables, such as Beta maritima L., Rumex papillaris Boiss. \& Reut., Rumex pulcher L. e Taraxacum obovatum (Willd.) DC. (Morales et al., 2012). R. raphanistrum leaves also revealed considerable values of palmitic (C16:0; $25.2 \mathrm{mg} / 100 \mathrm{~g} \mathrm{fw}$ ) and linoleic (C18:2n6; $24 \mathrm{mg} / 100 \mathrm{~g} \mathrm{fw}$ ) acids (Table 2).

Several studies have suggested that the consumption of food products of vegetable origin with high levels of $\alpha$-linolenic acid ( $\omega$-3) can reduce the risk of cardiovascular diseases, in particular when SFA are replaced by PUFA in a rate between 5 and $10 \%$ of the consumed energy (Lira, Barros Silva, Figueirêdo, \& Bragagnolo, 2014; Santos et al., 2013).

In addition, it has been reported that the ratio of $\omega-6 / \omega-3$ levels should be lower than 4.0 , since an unbalanced ratio due to the predominance of $\omega-6$ has been associated with prothrombotic and proinflammatory effects (Simopoulos, 2016). In this sense, the inclusion of $R$. raphanistrum in the diet, and its increased consumption, can be beneficial to health due to its interesting fatty acid profile (Table 2).

Vitamin $\mathrm{E}$ is constituted by four isoforms of $\alpha$-, $\beta$-, $\gamma$ - and $\delta$-tocopherols and $\alpha$-, $\beta-, \gamma$ - and $\delta$-tocotrienols, which have been associated with a variable of human health effects, acting as anti-inflammatory, antioxidants and neuroprotectors (Singh, Beattie, \& Seed, 2013). All the four isoforms of tocopherols were identified and quantified in the leaves of $R$. raphanistrum, with predominance of $\alpha$-tocopherol as show in Table 2.

The dietary reference intake for vitamin $\mathrm{E}$ (expressed only in the form of $\alpha$-tocopherol) provided by the Food and Nutrition Board of the Institute of Medicine, varies with ages, being the Recommended Dietary Allowances set between $6 \mathrm{mg}$ for 1 to 3 years old children to $19 \mathrm{mg} /$ day for breastfeeding women (Monsen, 2000; Institute of Medicine, 2000). Therefore, the consumption of wild radish leaves as a green vegetable in a varied and balanced diet contributes to attaining an adequate daily intake level of vitamin E $(1.07 \mathrm{mg} / 100 \mathrm{~g} \mathrm{fw}$, Table 2$)$.

\subsection{Chemical characterization of $R$. raphanistrum extracts}

Besides the chemical characterization of wild radish leaves, both prepared extracts (hydroalcoholic and decoction) were also evaluated regarding their composition in free sugars, organic acids, tocopherols and phenolic compounds. The analysis of these molecules in aqueous extracts is of great relevance, since it allows to determine the loss of compounds after a cooking process.

In both extracts, the main identified sugars were glucose and fructose. In comparison to the raw plant profile (Table 1), only trehalose was not identified in the extracts, possibly due to the low concentration of this sugar in the plant. A significantly higher total free sugars content was observed for the hydroalcoholic extract $(p<0.001)$ as show in Table 3, which may be due to factors described by Stalikas (2007), such as agitation and time of contact of the sample with the solvent.

Regarding the organic acids profile, both qualitative and quantitative differences were observed between the two extracts (Table 3). In contrast to total free sugars, a significantly higher amount of organic acids was found in the decoction extract $(435 \mathrm{mg} / \mathrm{g}$ decoction extract vs. $344 \mathrm{mg} / \mathrm{g}$ hydroalcoholic extract) (Table 3 ). This significant difference can be explained by the greater solubility of these compounds in water extract then in less polar extraction systems (Daneshfar et al.,
Table 3

Free sugars $(\mathrm{mg} / 100 \mathrm{~g}$ extract), organic acids (mg/100 g extract) and tocopherols (mg/100 g extract) of $R$. raphanistrum extracts (mean $\pm \mathrm{SD}$ ).

\begin{tabular}{llll}
\hline & Decoction & Hydroalcoholic & $t$-Students test \\
\cline { 4 - 4 } & & & $p$-value \\
\hline Free sugars & & & \\
Fructose & $27.8 \pm 0.3$ & $41.4 \pm 0.7$ & $<0.001$ \\
Glucose & $45.5 \pm 0.6$ & $65.5 \pm 0.4$ & $<0.001$ \\
Total free sugars & $73.3 \pm 0.9$ & $107 \pm 1$ & $<0.001$ \\
Organic acids & & & \\
Oxalic & $283 \pm 2$ & $344 \pm 3$ & $<0.001$ \\
Malic & $55.9 \pm 0.3$ & nd & - \\
Ascorbic & tr & $0.13 \pm 0.001$ & - \\
Citric & $96 \pm 2$ & nd & - \\
Fumaric & tr & tr & - \\
Total organic acids & $435 \pm 4$ & $344 \pm 3$ & $<0.001$ \\
Tocopherols & & & \\
$\alpha$-Tocopherol & nd & $99 \pm 1$ & - \\
Total tocopherols & nd & $99 \pm 1$ & - \\
& & & \\
\hline
\end{tabular}

nd - not detected (below LOD values); tr - traces (below LOQ values).

2012). Both extracts presented oxalic acid as predominant compound, however malic and citric acids were also present only in the decoction extract. The mixture of ethanol with water leads to the reduction of polarity, therefore leading to a decrease in the extraction of these compounds (Yuan, Leng, Shao, Huang, \& Shan, 2014). By the contrary, ascorbic acid was additionally present in the hydroalcoholic extract, while being only found in trace amounts in the decoction extract. This is most probably due to the use of high temperature during the decoction extraction process (Santos, 2013).

Concerning the tocopherols content, only $\alpha$-tocopherol was detected, being present uniquely in the hydroalcoholic extract (Table 3). The absence of this lipophilic compound in the decoction extract was expectable, mainly due to its non-solubility in aqueous solvents, but also due to the high temperature applied during the decoction extraction.

The analysis of phenolic compounds profile in $R$. raphanistrum extracts were performed by HPLC-DAD-ESI/MS ${ }^{\mathrm{n}}$ (Fig. 1). Data regarding the retention time, $\lambda_{\max }$, pseudomolecular ion, main fragment ions in $\mathrm{MS}^{2}$, tentative identification and quantification of the phenolic compounds are presented in Table 4. Fourteen phenolic compounds were identified, comprising two hydroxycinnamoylquinic acid derivatives (ferulic and $p$-coumaric acid derivatives) and twelve flavonols derivatives (quercetin and kaempferol glycoside derivatives).

In Table 4, peak $1\left([\mathrm{M}-\mathrm{H}]^{-}\right.$at $m / z$ 337) was identified as 3-p-coumaroylquinic, yielding the base peak at $m / z 191$ [quinic acid- $\mathrm{H}]^{-}$and also gave an ion at $m / z 173$ [coumaric acid-H] ${ }^{-}$with an intensity $43 \%$ of the base peak. Similar fragmentation pattern was already reported by Clifford, Johnston, Knight, and Kuhnert (2003) and Clifford, Knight, and Kuhnert (2005) and used to distinguish 3-acylcoumaric acids. Peak $2\left([\mathrm{M}-\mathrm{H}]^{-}\right.$at $\left.m / z 367\right)$ was identified as 3-O-feruloylquinic acid taking into account the same hierarchical keys previously developed by Clifford et al., (2003) and (2005). Both these compounds, as far as the authors knowledge were not reported previously in $R$. raphanistrum.

The following compounds were identified as quercetin $\left(\lambda_{\max }\right.$ around $353 \mathrm{~nm}$, and an $\mathrm{MS}^{2}$ fragment at $\left.m / z 301\right)$ and kaempferol $\left(\lambda_{\max }\right.$ around $346 \mathrm{~nm}$, and an $\mathrm{MS}^{2}$ fragment at $m / z 285$ ) glycoside derivatives. Peaks 3 and 4 presented the same pseudomolecular ion $[\mathrm{M}-\mathrm{H}]^{-}$at $m / z$ 609 , revealing the alternative loss of hexosyl $(\mathrm{m} / \mathrm{z}$ at $447 ;-162 \mathrm{u})$ and deoxyhexosyl $(\mathrm{m} / \mathrm{z}$ at $301 ;-146 \mathrm{u})$ residues, indicating location of each residue on different positions of the aglycone. These compounds were tentatively identified as quercetin- $O$-deoxyhexoside- $O$-hexoside isomers. Thus, similar compounds have been previously described in a $70 \%$ ethanolic extract of $R$. raphanistrum aerial parts collected from the Giza field, Egypt (Ibrahim et al., 2016), therefore similar assumption 
Hydroalcoholic extract

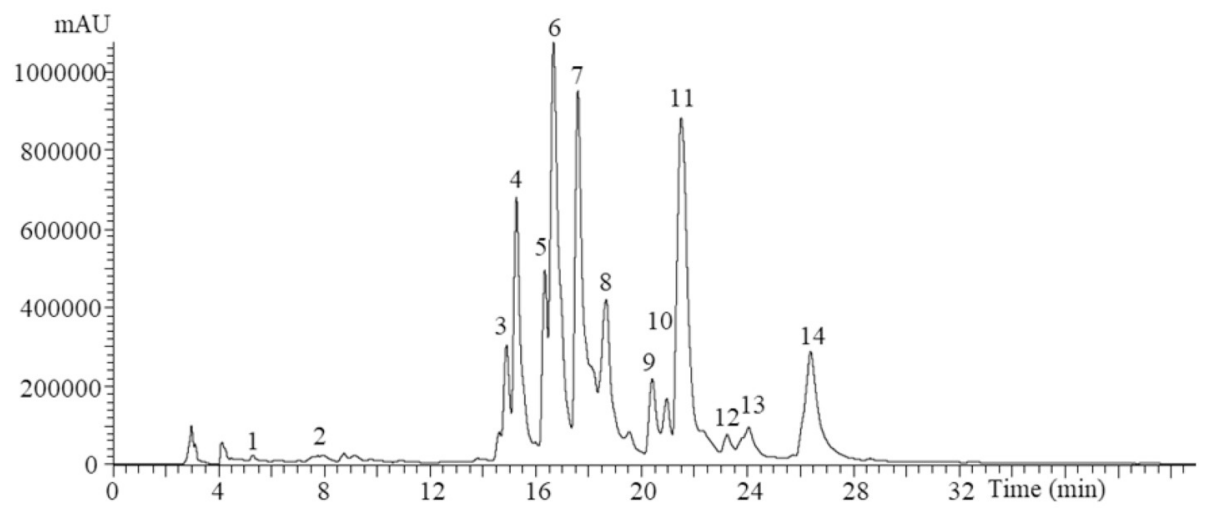

Decoction

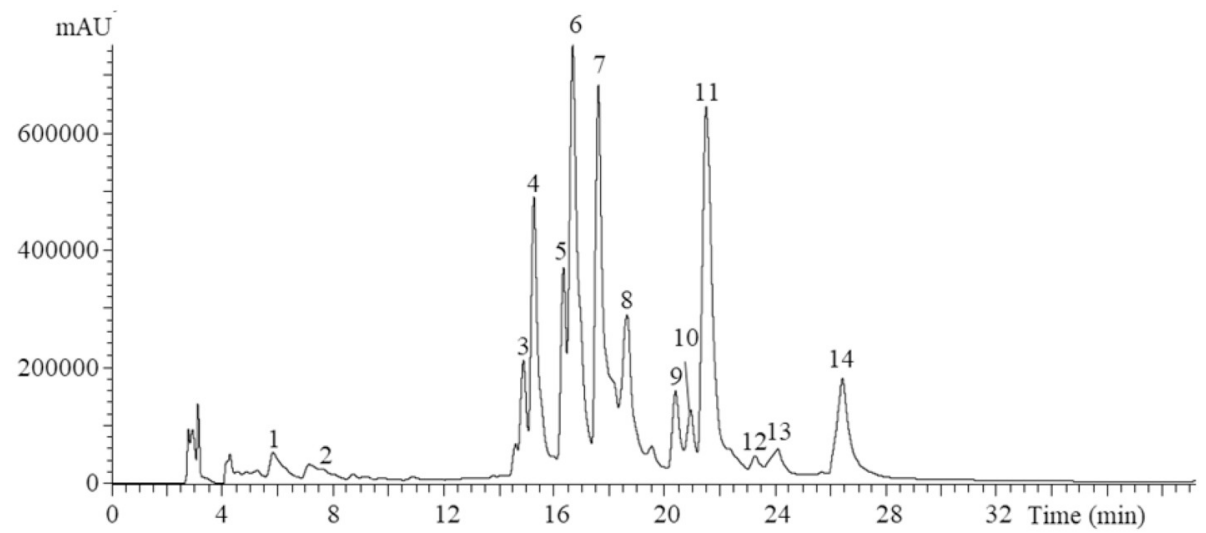

Fig. 1. Phenolic profile of the hydroalcoholic and decoction extracts of Raphanus raphanistrum recorded at $370 \mathrm{~nm}$. The numbers presented in the chromatograms correspond to the compounds identified in Table 4.

Table 4

Retention time (Rt), wavelengths of maximum absorption in the visible region $\left(\lambda_{\max }\right)$, mass spectral data, tentative identification, and a quantification estimation (mean \pm SD) of the tentatively identified phenolic compounds in decoction and hydroalcoholic extracts of $R$. raphanistrum.

\begin{tabular}{|c|c|c|c|c|c|c|c|c|}
\hline Peak & Rt & $\lambda \max$ & {$[\mathrm{M}-\mathrm{H}]^{-}$} & $\mathrm{MS}^{2}$ & Tentative identification & Decoction & Hydroalcoholic & $\begin{array}{l}t \text {-Students } \\
\text { test }\end{array}$ \\
\hline & $\min )$ & $(\mathrm{nm})$ & $(m / z)$ & $(m / z)$ & & (mg/g extract) & (mg/g extract) & $p$-value \\
\hline 1 & 6.41 & 313 & 337 & 191(100),173(42),163(5),147(3),129(2) & 3-p-Coumaroylquinic acid ${ }^{\mathrm{a}}$ & $0.52 \pm 0.01$ & $0.16 \pm 0.004$ & $<0.001$ \\
\hline 2 & 7.76 & 292,318 & 367 & $193(29), 191(100), 173(5), 147(5), 129(2)$ & 3-O-Feruloylquinic acid $^{\mathrm{a}}$ & $0.22 \pm 0.001$ & $0.175 \pm 0.001$ & $<0.001$ \\
\hline 3 & 14.88 & 255,353 & 609 & $463(60), 447(100), 301(15)$ & Quercetin-3-O-rhamnoside-7-O-glucoside ${ }^{\mathrm{b}}$ & $0.94 \pm 0.02$ & $1.2 \pm 0.03$ & $<0.001$ \\
\hline 4 & 15.25 & 254,353 & 609 & $463(49), 447(100), 301(15)$ & Quercetin-O-rhamnoside- $O$-glucoside ${ }^{\mathrm{b}}$ & $2.34 \pm 0.001$ & $3.63 \pm 0.01$ & $<0.001$ \\
\hline 5 & 16.31 & 263,346 & 771 & $285(100), 257(20), 151(13)$ & Kaempferol-O-tri-hexoside ${ }^{c}$ & $1.53 \pm 0.01$ & $1.88 \pm 0.005$ & $<0.001$ \\
\hline 6 & 16.65 & 264,348 & 593 & $447(100), 285(5)$ & Kaempferol-3-O-rhamnoside-7-O-glucoside $\mathrm{e}^{\mathrm{b}, \mathrm{c}}$ & $4.07 \pm 0.1$ & $6 \pm 0.2$ & $<0.001$ \\
\hline 7 & 17.58 & 263,346 & 593 & $447(100), 431(47), 285(8)$ & Kaempferol-O-rhamnoside-O-glucoside ${ }^{\text {b,c }}$ & $3.62 \pm 0.06$ & $4.47 \pm 0.02$ & $<0.001$ \\
\hline 8 & 18.64 & 263,347 & 563 & $417(100), 285(50), 257(5), 151(3)$ & Kaempferol-O-deoxyhexoside- $O$-pentoside ${ }^{c}$ & $1.8 \pm 0.1$ & $2.4 \pm 0.1$ & 0.001 \\
\hline 9 & 20.39 & 263,348 & 739 & $593(100), 431(20), 285(12)$ & $\begin{array}{l}\text { Kaempferol-3-O-(2"-glucosyl)-rhamnoside-7- } \\
O \text {-rhamnoside }{ }^{\text {b }}\end{array}$ & $1.04 \pm 0.004$ & $1.44 \pm 0.01$ & $<0.001$ \\
\hline 10 & 20.90 & 261,326 & 931 & 785(100),609(18),285(5) & $\begin{array}{l}\text { Kaempferol-3-O-feruloyldihexoside-7-O- } \\
\text { rhamnoside }^{\mathrm{d}}\end{array}$ & $0.85 \pm 0.005$ & $1.1 \pm 0.03$ & $<0.001$ \\
\hline 11 & 21.48 & 263,346 & 577 & $431(100), 285(11)$ & Kaempferol-3,7-O-di-rhamnoside ${ }^{\mathrm{d}}$ & $4.85 \pm 0.1$ & $7.5 \pm 0.1$ & $<0.001$ \\
\hline 12 & 23.19 & 261,330 & 917 & $771(5), 609(100), 285(11)$ & $\begin{array}{l}\text { Kaempferol-3-O-caffeoyldihexoside-7-O- } \\
\text { rhamnoside }^{\mathrm{d}}\end{array}$ & $0.47 \pm 0.02$ & $0.7 \pm 0.02$ & $<0.001$ \\
\hline 13 & 24.03 & 252,332 & 947 & $801(100), 625(22), 301(15)$ & $\begin{array}{l}\text { Quercetin-3-O-feruloyldihexoside-7-O- } \\
\text { rhamnoside }^{\mathrm{d}}\end{array}$ & $0.68 \pm 0.04$ & $0.8 \pm 0.02$ & 0.002 \\
\hline \multirow[t]{4}{*}{14} & 26.37 & 262,330 & 931 & 785(100),609(11),285(5) & $\begin{array}{l}\text { Kaempferol- } O \text {-feruloyldihexoside- } O \text { - } \\
\text { rhamnoside }^{\mathrm{d}}\end{array}$ & $1.84 \pm 0.04$ & $2.5 \pm 0.02$ & $<0.001$ \\
\hline & & & & & Total phenolic acids & $0.74 \pm 0.01$ & $0.33 \pm 0.01$ & $<0.001$ \\
\hline & & & & & Total flavonoids & $24.02 \pm 0.4$ & $33.26 \pm 0.5$ & $<0.001$ \\
\hline & & & & & Total phenolic compounds & $24.76 \pm 0.4$ & $33.59 \pm 0.5$ & $<0.001$ \\
\hline
\end{tabular}

Calibration curves: Peak $1:$ p-coumaric acid $\left(\mathrm{y}=301,950 \times+6966.7 ; \quad R^{2}=0.999 ; \quad\right.$ LOD $=0.68 \mu \mathrm{g} / \mathrm{mL} ; \quad$ LOQ $\left.=1.61 \mu \mathrm{g} / \mathrm{mL}\right) ; \quad$ Peak $\quad 2$ - ferulic acid $\left(\mathrm{y}=633,126 \times-185,462 ; R^{2}=0.999 ; \mathrm{LOD}=0.20 \mu \mathrm{g} / \mathrm{mL} ; 1.01 \mu \mathrm{g} / \mathrm{mL}\right) ;$ peaks 3 to 14 : quercetin 3-O-glucoside $\left(\mathrm{y}=34,843 \times-160,173 ; R^{2}=0.9998\right.$; $\mathrm{LOD}=0.21 \mu \mathrm{g} / \mathrm{mL} ; \mathrm{LOQ}=0.71 \mu \mathrm{g} / \mathrm{mL}$ ). References applied for the tentative identification: a - Clifford et al. (2003), Clifford et al. (2005); b - Ibrahim et al. (2016), c -DAD and MS fragmentation pattern; d - Lin et al. (2014). 
Table 5

Antioxidant and hepatotoxicity activities of $R$. raphanistrum extracts (mean $\pm \mathrm{SD})$.

\begin{tabular}{|c|c|c|c|}
\hline & \multicolumn{2}{|c|}{ R. raphanistrum } & \multirow{2}{*}{$\begin{array}{l}t \text {-Students } \\
\text { test } \\
p \text {-value }\end{array}$} \\
\hline & Decoction & Hydroalcoholic & \\
\hline \multicolumn{4}{|l|}{ Antioxidant activity } \\
\hline $\begin{array}{l}\text { DPPH scavenging activity } \\
\qquad\left(\mathrm{EC}_{50}{ }^{\mathrm{a}} ; \mathrm{mg} / \mathrm{mL}\right)\end{array}$ & $4.0 \pm 0.1$ & $3.12 \pm 0.07$ & $<0.001$ \\
\hline $\begin{array}{l}\text { Ferricyanide/Prussian blue } \\
\quad\left(\mathrm{EC}_{50}{ }^{\mathrm{b}} ; \mathrm{mg} / \mathrm{mL}\right)\end{array}$ & $3.23 \pm 0.03$ & $1.01 \pm 0.01$ & $<0.001$ \\
\hline $\begin{array}{l}\beta \text {-carotene/linoleate }\left(\mathrm{EC}_{50}{ }^{\mathrm{a}} \text {; }\right. \\
\mathrm{mg} / \mathrm{mL})\end{array}$ & $0.56 \pm 0.02$ & $0.26 \pm 0.03$ & $<0.001$ \\
\hline TBARS $\left(\mathrm{EC}_{50}{ }^{\mathrm{a}} ; \mathrm{mg} / \mathrm{mL}\right)$ & $0.16 \pm 0.06$ & $0.108 \pm 0.007$ & 0.022 \\
\hline \multicolumn{4}{|l|}{ Hepatotoxicity (GI50 $\mu \mathrm{g} / \mathrm{mL}$ ) } \\
\hline $\begin{array}{l}\text { PLP2 (porcine liver primary } \\
\text { culture) }\end{array}$ & $>400$ & $>400$ & - \\
\hline
\end{tabular}

$\mathrm{EC}_{50}$ : extract concentration corresponding to ${ }^{\mathrm{a}} 50 \%$ of antioxidant activity or ${ }^{\mathrm{b}}$ 0.5 of absorbance in the reducing power assay. Trolox $\mathrm{EC}_{50}$ values: $41 \mu \mathrm{g} / \mathrm{mL}$ (reducing power), $42 \mu \mathrm{g} / \mathrm{mL}$ (DPPH scavenging activity), $18 \mu \mathrm{g} / \mathrm{mL}$ ( $\beta$-carotene bleaching inhibition) and $23 \mu \mathrm{g} / \mathrm{mL}$ (TBARS inhibition). $\mathrm{GI}_{50}$ values correspond to the sample concentration responsible for $50 \%$ inhibition of growth in a primary culture of liver cells-PLP2. $\mathrm{GI}_{50}$ values for Ellipticine (positive control): $3 \mu \mathrm{g} / \mathrm{mL}$ (PLP2).

were taken into account for these compounds, being tentatively assigned as quercetin-3-O-rhamnoside-7-O-glucoside and quercetin-Orhamnoside- $O$-glucoside, respectively. Similarly, and taking into account the mentioned assumptions, compounds 6 and $7\left([\mathrm{M}-\mathrm{H}]^{-}\right.$at $\mathrm{m} / \mathrm{z}$ 593) were tentatively identified as kaempferol-3-O-rhamnoside-7-Oglucoside and kaempferol-O-rhamnoside-O-glucoside, respectively. Compound $9\left([\mathrm{M}-\mathrm{H}]^{-}\right.$at $m / z$ 739) should correspond to a kaempferol derivative bearing two deoxyhexosyl $(-146 \mathrm{u})$ and one hexosyl $(-162$ u) residues. A compound with similar mass characteristics, i.e., kaempferol-3-O-(2"-glucosyl)-rhamnoside-7-O-rhamnoside, was reported in $R$. raphanistrum by Ibrahim et al. (2016), thus this compound was tentatively identified as that molecule. Mass characteristics of compound $5\left([\mathrm{M}-\mathrm{H}]^{-}\right.$at $\left.m / z 771\right)$ indicated that it also corresponds to a kaempferol derivative bearing three hexosyl residues $(-486 \mathrm{u})$, the observation of only one $\mathrm{MS}^{2}$ fragment suggested that the three sugars were linked together, suggesting that the sugars constituted a trisaccharide (tri-hexoside), thus information about the identity of the sugar moieties and location onto the aglycone could not be obtained, so, the compound was tentatively identified as kaempferol-O-tri-hexoside. Compound $8\left([\mathrm{M}-\mathrm{H}]^{-}\right.$at $\left.m / z 563\right)$ presented two $\mathrm{MS}^{2}$ fragments at $m / z 417$ ( $-146 \mathrm{u}$, deoxyhexosyl moiety) and 285 ( $-132 \mathrm{u}$, pentosyl moiety), indicating alternative losses of each sugar moieties, pointing to their location on different positions of the aglycone, thus being tentatively identified as kaempferol-O-deoxyhexoside- $O$-pentoside. To the best of our knowledge both these compounds was not previously identified in $R$. raphanistrum. Compound $11\left([\mathrm{M}-\mathrm{H}]^{-}\right.$at $\left.\mathrm{m} / \mathrm{z} 577\right)$ showed a similar fragmentation pattern as peak 8 , with the respective losses of two deoxyhexosyl moieties ( $-146 \mathrm{u}$ ), and presenting a typical fragmentation pattern as kaempferol. A compound with similar mass characteristics, kaempferol-3,7-O-di-rhamnoside, was previously reported in Rorippa indica (Linn.), a plant species from the same family (Lin et al., 2014), thus this assumption was tentatively performed for this compound.

The remaining compounds (10 and 12-14) were all identified as acylated flavonols due to the observation of a loss of a feruloyl residue $(-176 u)$ or caffeoyl $(-162 u)$, which is coherent with all the identities of the remaining compounds, as well as their late elution, since the presence of the hydroxycinnamoyl residue implies a decrease in polarity, as also to their lower maximum absorbance. All these peaks were previously identified by Lin et al. (2014) and the assumptions were also taken into account for the species studied herein. Compounds 10 and 14 $\left([\mathrm{M}-\mathrm{H}]^{-}\right.$at $m / z$ 931) and $13\left([\mathrm{M}-\mathrm{H}]^{-}\right.$at $m / z$ 947), all presented a similar fragmentation pattern, revealing tree $\mathrm{MS}^{2}$ fragments representing the successive loss of a deoxyhexosyl $(-146 \mathrm{u})$, feruloyl $(-176 \mathrm{u})$ and di-hexosyl $(-324 \mathrm{u})$ residues. Taking into account the similar fragmentation pattern mentioned by Lin et al. (2014), these compounds were identified as kaempferol-3-O-feruloyldihexoside-7-Orhamnoside, kaempferol-O-feruloyldihexoside-O-rhamnoside, and quercetin-3-O-feruloyldihexoside-7-O-rhamnoside, respectively. Similarly, compound $12\left([\mathrm{M}-\mathrm{H}]^{-}\right.$at $m / z$ 917) also revealed the presence of three $\mathrm{MS}^{2}$ fragments at $m / z 771(-146 \mathrm{u}$, loss of a deoxyhexosyl moiety), 609 ( $-162 \mathrm{u}$, loss of a caffeoyl moiety) and 285 [kaempferol$\mathrm{H}]^{-}(-324 \mathrm{u}$, loss of a di-hexosyl residue), thus being tentatively assigned to a similar compound, with the same DAD and MS characteristics, as kaempferol-3-O-caffeoyldihexoside-7-O-rhamnoside.

The hydroethanolic extract presented a higher concentration in the tentatively identified phenolic compounds, in which flavonols were present in higher abundance (97-99\% of the total phenolic content), being kaempferol-3,7-O-di-rhamnoside the most abundant compound in both extracts. Although the extraction of phenolic compounds is superior in the hydroalcoholic extract the values obtained for the decoctions are also relevant, since this plant can be consumed after cooking. The results demonstrate that the water used in the decoction extract promotes the extraction of phenolic compounds, thus the nonuse of the cooking water implies the loss of many of these compounds in particular of the phenolic acids, which are found in higher amounts in the decoction extract.

\subsection{Bioactive properties of $R$. raphanistrum hydroalcoholic and decoction extracts}

Edible wild plants are commonly used as foods, nonetheless several are also used as traditional herbal medicines (Özen, 2010). Besides being consumed raw or cooked, $R$. raphanistrum has also been associated with beneficial properties, being traditionally used in treatment of hepatobiliary affections, dyspeptic problems, mainly related with biliary dyskinesia and bronchial affections (Neto \& Simões, 2016). Therefore, this study also comprised the evaluation of different biological properties, namely antioxidant, cytotoxic and antimicrobial activities.

Data regarding the antioxidant and hepatotoxicity activities are presented in Table 5. Four different antioxidant activity assays (DPPH scavenging activity, reducing power, $\beta$-carotene bleaching inhibition and TBARS inhibition assays) were performed. For both extracts, the lowest $\mathrm{EC}_{50}$ values (highest antioxidant activity) were observed in the TBARS inhibition and $\beta$-Carotene bleaching inhibition assays. Additionally, results show that, for all the four methods assayed, the hydroalcoholic extract exhibited a higher antioxidant potential compared to the decoction. Nevertheless, this last extract still presents interesting results, evidencing that a substantial loss of antioxidants occurs into the boiling water when wild radish is cooked. Therefore, its consumption can be more beneficial in the form of soups than as boiled vegetables. The superior antioxidant activity obtained for the hydroalcoholic extract may be explained by its higher content of phenolic compounds and tocopherols.

The antioxidant activity determined by the DPPH method of an aqueous extract of $R$. raphanistrum prepared by maceration at room temperature, has been previously reported by Küçükboyaci, Güvenç, Turan, and Aydin (2012). In that work a higher $\mathrm{EC}_{50}$ value was reported $(8.78 \mathrm{mg} / \mathrm{mL})$, corresponding to a lower antioxidant activity compared to the plant herein studied, which could be related to the different extraction procedures applied in both studies, but also to different applied solvents, in the case of the hydroethanolic extract. The extraction methodology highly affects the extraction of compounds, as it visual in the present, were the hydroethanolic extract presented a higher bioactivity in comparison to the aqueous extract. Moreover, these 
Table 6

Antimicrobial activity of the studied plant $R$. raphanistrum extracts (mean).

\begin{tabular}{|c|c|c|c|c|c|c|c|c|c|c|}
\hline & \multicolumn{2}{|c|}{ Hydroalcoholic } & \multicolumn{2}{|c|}{ Decoction } & \multicolumn{2}{|c|}{$\frac{\text { Ampicillin }}{(20 \mathrm{mg} / \mathrm{mL})}$} & \multicolumn{2}{|l|}{$\frac{\text { Imipenem }}{(1 \mathrm{mg} / \mathrm{mL})}$} & \multicolumn{2}{|c|}{$\frac{\text { Vancomycin }}{(1 \mathrm{mg} / \mathrm{mL})}$} \\
\hline & MIC & MBC & MIC & MBC & MIC & MBC & MIC & MBC & MIC & MBC \\
\hline \multicolumn{11}{|l|}{ Gram-negative bacteria } \\
\hline Escherichia coli & 2.5 & 20 & 2.5 & 20 & $<0.15$ & $<0.15$ & $<0.0078$ & $<0.0078$ & nt & nt \\
\hline Klebsiella pneumoniae & 10 & 20 & 10 & 20 & 10 & 20 & $<0.0078$ & $<0.0078$ & nt & nt \\
\hline Morganella morganii & 10 & 20 & 10 & 20 & 20 & $>20$ & $<0.0078$ & $<0.0078$ & nt & nt \\
\hline Proteus mirabilis & $>20$ & $>20$ & $>20$ & $>20$ & $<0.15$ & $<0.15$ & $<0.0078$ & $<0.0078$ & nt & nt \\
\hline Pseudomonas aeruginosa & $>20$ & $>20$ & $>20$ & $>20$ & $>20$ & $>20$ & 0.5 & 1 & $\mathrm{nt}$ & nt \\
\hline \multicolumn{11}{|l|}{ Gram-positive bacteria } \\
\hline Enterococcus faecalis & 20 & $>20$ & 20 & $>20$ & $<0.15$ & $<0.15$ & nt & nt & $<0.0078$ & $<0.0078$ \\
\hline Listeria monocytogenes & 5 & 20 & 5 & 20 & $<0.15$ & $<0.15$ & nt & $\mathrm{nt}$ & nt & nt \\
\hline MRSA & 10 & $>20$ & 10 & $>20$ & $<0.15$ & $<0.15$ & nt & nt & $<0.0078$ & $<0.0078$ \\
\hline
\end{tabular}

MRSA: Methicillin resistant Staphylococcus aureus; MIC: minimal inhibitory concentration; MBC: minimal bactericidal concentration; nt: not tested.

differences could also be due to other factors, that are known to affect the chemical composition of plants, such as the timing of harvesting, geographic location/climate and the plant adaptation to the soil conditions (Sampaio, Edrada-Ebel, \& Da Costa, 2016). Additionally, differences in plants genotype may be associated with chemical variability, therefore affecting its bioactivity.

Concerning the evaluation of in vitro cytotoxic activity in nontumor cells, both extracts did not presented activity against porcine hepatic cells, in the tested concentrations (Table 5).

Regarding the antibacterial activity results, no differences were found between the two evaluated extracts, being both active against six of the eight tested bacteria (Table 6). Both extracts showed the lowest MIC values against Gram-positive bacteria, namely against $E$. coli (MIC $=2.5 \mathrm{mg} / \mathrm{mL}$ ) and L. monocytogenes ( $\mathrm{MIC}=5 \mathrm{mg} / \mathrm{mL}$ ). The extracts also exhibited bactericidal effect against these two bacteria, frequently associated to foodborne diseases, although higher concentrations were needed $(\mathrm{MBC}=20 \mathrm{mg} / \mathrm{mL})$ to achieve the growth inhibition. In the tested concentrations, both type of extracts were ineffective against the Gram-negative bacteria $P$. mirabilis and $P$. aeruginosa. While previous works have reported the antimicrobial activity of the crude juice or extracts of $R$. sativus (red radish) against a broad range of bacteria (Kaymak, Ozturk, Ercisli, \& Guvenc, 2015), as far as we know, there is no previous data regarding the antimicrobial activity of wild radish.

\section{Conclusion}

An extensive and detailed study comprising the chemical characterization of $R$. raphanistrum leaves, including its composition in nutritional compounds, free sugars, organic acids, fatty acids, vitamin $\mathrm{E}$ (tocopherols) and phenolic compounds was performed. The obtained results evidenced that wild radish is a good source of several beneficial health compounds, including PUFA fatty acids, $\alpha$-tocopherol, phenolic compounds. Most phenolic compounds found in its composition were reported for the first time and included mainly kaempferol derivatives, but also quercetin derivatives and two caffeic acid derivatives. In addition to presenting a low energetic value, wild radish also showed higher protein and lower lipid content when compared to other green vegetables belonging to Brassicaceae family.

Both hydroalcoholic and decoction extracts showed antioxidant and antibacterial activity, without evidencing cytotoxicity against non-tumoral liver cells. The extracts were able to inhibit a broad range of bacteria, including both Gram-positive and Gram-negative bacteria, with a higher effect being observed against the former.

Overall, the obtained results demonstrate that $R$. raphanistrum can be a sustainable source of nutrients and compounds with high bioactive potential, highlighting the interest of incorporating this edible wild plant as a vegetable in a diversified and healthy diet.

\section{Acknowledgements}

The authors are grateful to the Foundation for Science and Technology FCT, Portugal and FEDER under Programme PT2020 for financial support to CIMO (UID/AGR/00690/2013), L. Barros and A. Fernandes contracts. This work was also funded by FEDER-Interreg España-Portugal programme through the project 0377_Iberphenol_6_E.

\section{References}

Abreu, R. M. V., Ferreira, I. C. F. R., Calhelha, R. C., Lima, R. T., Vasconcelos, M. H., Adega, F., ... Queiroz, M. J. R. P. (2011). Anti-hepatocellular carcinoma activity using human HepG2 cells and hepatotoxicity of 6-substituted methyl 3-aminothieno[3,2-b] pyridine-2- carboxylate derivatives: In vitro evaluation, cell cycle analysis and QSAR studies. European Journal of Medicinal Chemistry, 46, 5800-5806.

AOAC (2016). Official methods of analysis of AOAC international (20th ed). Rockville, MD, USA: The Association of Official Analytical Chemists International.

Barros, L., Carvalho, A. M., Morais, J. S., \& Ferreira, I. C. F. R. (2010). Strawberry-tree, blackthorn and rose fruits: Detailed characterization in nutrients and phytochemicals with antioxidant properties. Food Chemistry, 120, 247-254.

Barros, L., Pereira, E., Calhelha, R. C., Dueñas, M., Carvalho, A. M., Santos-Buelga, C., \& Ferreira, I. C. F. R. (2013). Bioactivity and chemical characterization in hydrophilic and lipophilic compounds of Chenopodium ambrosioides L. Journal of Functional Foods, 5, 1732-1740.

Benevides, C. M., de, J., Souza, M. V., Souza, R. D. B., \& Lopes, M. V. (2011). Fatores antinutricionais em alimentos: revisão Antinutritional factors in foods: A review. Segurança Alimentar e Nutricional, 18, 67-79.

Bessada, S. M. F., Barreira, J. C. M., Barros, L., Ferreira, I. C. F. R., \& Oliveira, M. B. P. P. (2016). Phenolic profile and antioxidant activity of Coleostephus myconis (L.) Rchb.f.: An underexploited and highly disseminated species. Industrial Crops and Products, 89, 45-51.

Bicho, R. C. (2015). Regulamentação europeia sobre novel food: Identificação de plantas silvestres comestiveis nacionais como não novo alimento. Universidade de Lisboa.

Clifford, M. N., Johnston, K. L., Knight, S., \& Kuhnert, N. (2003). Hierarchical scheme for LC-MSn identification of chlorogenic acids. Journal of Agricultural and Food Chemistry, $51,2900-2911$.

Clifford, M. N., Knight, S., \& Kuhnert, N. (2005). Discriminating between the six isomers of dicaffeoylquinic acid by LC-MSn. Journal of Agricultural and Food Chemistry, 53, 3821-3832.

Daneshfar, A., Baghlani, M., Sarabi, R. S., Sahraei, R., Abassi, S., Kaviyan, H., \& Khezeli, T. (2012). Solubility of citric, malonic, and malic acids in different solvents from 303.2 to 333.2K. Fluid Phase Equilibria, 313, 11-15.

Ferreira, I. C. F. R., Morales, P., \& Barros, L. (2016). Wild plants, mushrooms and nuts: Functional food properties and applications. Wiley-Blackwell.

Food Ingredients Brasil (2015). Os Ácidos Na Indústria Alimentícia. Food Ingredients Brasil, 35, 58-67.

Goyeneche, R., Roura, S., Ponce, A., Vega-Gálvez, A., Quispe-Fuentes, I., Uribe, E., \& Di Scala, K. (2015). Chemical characterization and antioxidant capacity of red radish (Raphanus sativus L.) leaves and roots. Journal of Functional Foods, 16, 256-264.

Ibrahim, L. F., Elkhateeb, A., Marzouk, M. M., Hussein, S. R., Abdel-Hameed, E.-S. S., \& Kassem, M. E. S. (2016). Flavonoid investigation, LC - ESI-MS profile and cytotoxic activity of Raphanus raphanistrum L. (Brassicaceae). Journal of Chemical and Pharmaceutical Research, 8, 786-793.

Kala, A., \& Prakash, J. (2006). The comparative evaluation of the nutrient composition and sensory attributes of four vegetables cooked by different methods. International Journal of Food Science and Technology, 41, 163-171. 
Kaymak, H. C., Ozturk, S., Ercisli, S., \& Guvenc, I. (2015). In vitro antibacterial activities of black and white radishes (Raphanus Sativus L.). Comptes Rendus de L'Academie Bulgare des Sciences: Sciences Mathematiques et Naturelles, 68, 201-208.

Küçükboyaci, N., Güvenç, A., Turan, N. N., \& Aydin, A. (2012). Antioxidant activity and total phenolic content of Aqueius extract from Raphanus raphanistrum L. Turkish Journal of Pharmaceutical Sciences, 9, 93-100.

Lin, L. Z., Sun, J., Chen, P., Zhang, R. W., Fan, X. E., Li, L. W., \& Harnly, J. M. (2014). Profiling of glucosinolates and flavonoids in rorippa indica (Linn.) Hiern. (cruciferae) by UHPLC-PDA-ESI/HRMSn. Journal of Agricultural and Food Chemistry, 62, 6118-6129.

Lira, G. M., Barros Silva, K. W., Figueirêdo, B. C., \& Bragagnolo, N. (2014). Impact of smoking on the lipid fraction and nutritional value of seabob shrimp (Xiphopenaeus kroyeri, Heller, 1862). LWT - Food Science and Technology, 58, 183-187.

Łuczaj, Ł., Pieroni, A., Tardío, J., Pardo-De-Santayana, M., Sõukand, R., Svanberg, I., \& Kalle, R. (2012). Wild food plant use in 21st century Europe: The disappearance of old traditions and the search for new cuisines involving wild edibles. Acta Societatis Botanicorum Poloniae, 81, 359-370.

Maldini, M., Foddai, M., Natella, F., Petretto, G. L., Rourke, J. P., Chessa, M., \& Pintore, G. (2017). Identification and quantification of glucosinolates in different tissues of Raphanus raphanistrum by liquid chromatography tandem-mass spectrometry. Journal of Food Composition and Analysis, 61, 20-27.

Monsen, E. R. (2000). Dietary reference intakes for the antioxidant nutrients Vitamin C Vitamin E selenium and carotenoids.pdf. Journal of the American Dietetic Association, 100, 637-640.

Morales, P., Ferreira, I. C. F. R., Carvalho, A. M., Sánchez-Mata, M. C., Cámara, M., \& Tardío, J. (2012). Fatty acids profiles of some Spanish wild vegetables. Food Science and Technology International, 18, 281-290.

NEPA - Núcleo de Estudos e Pesquisas em Alimentação (2011). Tabela brasileira de composição de alimentos. NEPA - Unicamp161.

Neto, F. C., \& Simões, M. T. F. (2016). As Plantas Medicinais, Aromáticas e Condimentares da Terra Fria Transmontana. Bragança: DRAP-Norte.

Obodai, M., Mensah, D. L. N., Fernandes, Â., Kortei, N. K., Dzomeku, M., Teegarden, M., \& Ferreira, I. C. F. R. (2017). Chemical characterization and antioxidant potential of wild ganoderma species from Ghana. Molecules, 22, 18.

de Oliveira, M. I. V., Pereira, E. M., Porto, R. M., Leite, D. D.d. F., Fidelis, V. R.d. L., \& Magalhaes, W. B. (2016). Avaliação da qualidade pós-colheita de hortaliças tipo fruto, comercializadas em feira livre no município de Solânea-PB, Brejo Paraibano. Revista Agropecuária Técnica, 37, 13-18.
Özen, T. (2010). Antioxidant activity of wild edible plants in the Black Sea Region of Turkey. Grasas y Aceites, 61, 86-94.

Pinela, J., Carvalho, A. M., \& Ferreira, I. C. F. R. (2017). Wild edible plants: Nutritional and toxicological characteristics, retrieval strategies and importance for today's society. Food and Chemical Toxicology, 110, 165-188.

Pires, T. C. S. P., Dias, M. I., Barros, L., Calhelha, R. C., Alves, M. J., Oliveira, M. B. P. P., \& Ferreira, I. C. F. R. (2018). Edible flowers as sources of phenolic compounds with bioactive potential. Food Research International, 105, 580-588.

Sampaio, B. L., Edrada-Ebel, R., \& Da Costa, F. B. (2016). Effect of the environment on the secondary metabolic profile of Tithonia diversifolia: A model for environmental metabolomics of plants. Scientific Reports, 6, 1-11.

dos Santos, A. A. (2013). Avaliação da bioatividade e caracterização química de uma espécie medicinal de uso tópico: Juglans regia L. Instituto Politécnico de Bragança. Retrieved from https://bibliotecadigital.ipb.pt/handle/10198/9198.

Santos, R. D., Gagliardi, A., Xavier, H., Magnoni, C., Cassani, R., Lottenberg, A., \& Ramos, S. (2013). I Diretriz sobre o Consumo de Gorduras e Saúde Cardiovascular. Arquivos Brasileiros de Cardiologia, 100, 1-40.

Sarmento, A., Barros, L., Fernandes, Â., Carvalho, A. M., \& Ferreira, I. C. F. R. (2015) Valorization of traditional foods: Nutritional and bioactive properties of Cicer arietinum L. and Lathyrus sativus L. pulses. Journal of the Science of Food and Agriculture, 95, 179-185.

Scalon, V. R., \& Souza, V. C. (2002). BRASSICACEAE. In M. Das, G. L. Wanderley, G. J. Shepherd, A. M. Giulietti, T. S. Melhem, V. Bittrich, \& C. Kameyama (Vol. Eds.), Flora Fanerogâmica do Estado de São Paulo. Vol. 2. Flora Fanerogâmica do Estado de São Paulo (pp. 57-64). São Paulo: Editora HUCITEC.

Simopoulos, A. (2016). An increase in the omega-6/omega-3 fatty acid ratio increases the risk for obesity. Nutrients, 8, 128.

Singh, V. K., Beattie, L. A., \& Seed, T. M. (2013). Vitamin E: Tocopherols and tocotrienols as potential radiation countermeasures. Journal of Radiation Research, 54, 973-988.

Stalikas, C. D. (2007). Extraction, separation, and detection methods for phenolic acids and flavonoids. Journal of Separation Science, 30, 3268-3295.

USDA (2016). United States Department of Agriculture Food Composition Databases. Retrieved from https://ndb.nal.usda.gov/ndb/, Accessed date: July 2018.

Vega, P. V., \& Florentino, B. L. (2000). Toxicologia de alimentos. Instituto Nacional de Salud Pública. Centro Nacional de Salud Ambiental (2nd ed.). México: Instituto Nacional de Salud Publica Centro Nacional de Salud Ambiental.

Yuan, Y., Leng, Y., Shao, H., Huang, C., \& Shan, K. (2014). Solubility of dl-malic acid in water, ethanol and in mixtures of ethanol + water. Fluid Phase Equilibria, 377, 27-32. 